\title{
KPMG Vak'ası: PCAOB Verilerinin Yasadışı Kullanımı ve Eğitim Sınavlarında Hile Yapılması
}

\author{
KMPG Case: Illicit Use of PCAOB Data and Cheating on \\ Training Exams
}

\author{
Neriman Yalçın ${ }^{1}$ \\ ${ }^{1}$ Dr. Öğr. Üyesi, Osmaniye Korkut Ata Üniversitesi, Kadirli Meslek Yüksekokulu, Osmaniye, Türkiye \\ ORCID: N.Y. 0000-0002-2196-4779
}

öz

ABD'de 2017 yılında dört büyük denetim firmasından biri olan KPMG’de, PCAOB çalışanlarının da dâhil olduğu bir skandal ortaya çıkmıştır. Söz konusu skandal 2015-2017 yılı incelemeleri hakkında PCAOB’un gizli verilerinin yasadışı yollarla elde edilmesi ve çıkar amaçı kullanımı eylemlerinden oluşmaktadır. Bu skandal hakkında yapılan incelemeler esnasında, PCAOB tarafından ikinci bir ihlal daha ortaya çıkarılmış ve KPMG'nin, yine 20152017 yıllarında denetim personeline uygulanan eğitim sınavlarında hile yaptı̆̆ı tespit edilmiştir.

Bu çalışma sözü edilen her iki ihlali inceleyen bir vaka incelemesi olarak gerçekleştirilmiştir. Bu kapsamda çalışmanın amacı; 2015-2017 yılları arasında ABD’de gerçekleşen KPMG skandalını kamuya açıklanmış tüm yönleriyle ortaya koymak, PCAOB’un skandal içindeki rolünü tartışmak ve bu vakada gerçekleşen eylemlerin ihlal ettiği denetim standartları ve etik ilkeleri tespit etmektir. Araştırma sonuçları, ihlal edilen ilkeleri belirlemek suretiyle, bir denetimin geçerli olarak kabul edilmesi için gereken şartların önemine dikkat çekmektedir. Ayrıca bu ve benzeri skandalların denetim kuruluşlarının ve kamu gözetimi kurumlarının kamuoyundaki güvenilirliklerine gölge düşürdüğü tekrar vurgulanmıştır.

Anahtar kelimeler: Denetim skandallar1, SOX, PCAOB, KPMG

\section{ABSTRACT}

A scandal involving employees of PCAOB and KPMG, one of the four big auditing firms in the USA, was uncovered in 2017. The scandal involved illegal access to confidential PCAOB data regarding inspections of the firm that would be conducted by the PCAOB between 2015 and 2017 , and use of the data for benefit-oriented purposes. During the investigation of this scandal, a second violation was unearthed by PCAOB, whereby KPMG was found to have been cheating on training exams for audit professionals in the period of 2015-2017. This case study examines the two violations mentioned above. This study aims to analyze the KPMG case through all the aspects disclosed to the public, to discuss PCAOB's role in the case, and to determine the ethical principles and auditing standards that were violated in this case. By identifying the principles that were violated, this study emphasizes the importance of prerequisites for an audit to be considered valid. This study also reiterates that such scandals bring the reliability of audit institutions and public oversight authorities into public disrepute.

Keywords: Audit scandals, SOX, PCAOB, KPMG

Başvuru/Submitted: 19.05.2020 Revizyon Talebi/Revision Requested: 05.06.2020 Son Revizyon/Last Revision Received: 15.06.2020 Kabul/Accepted: 04.07.2020 Sorumlu yazar/Corresponding author: Neriman Yalçın / nerimanyalcin@gmail.com 


\section{Extended Abstract}

The goal of this research was to reveal the KPMG scandal that came to light between 2015 and 2017, to discuss the role of PCAOB within the scandal, and to determine which audit standard and ethical principles were violated by the actions of this case. Thus, the efficiency of the performance of public oversight authorities related to 'inspection of audit' has been reviewed.

Financial scandals such as World.com, Parmalat, Xerox, and notably Enron have caused the reliability of financial statements and audit reports of related public financial statements to be questioned. A comprehensive text was prepared to provide and sustain quality in inspection in the USA and this was published under the title of 'SOX Code' on July 30, 2002. SOX is the USA federal law that specifies new or extended conditions for all public company management and accounting firms. The primary aims of related law are as follows: inspector independence, rotation condition, corporate responsibility, and establishing public oversight authority (PCAOB). SOX law organizes the establishment, goals, and duties of PCAOB and also its 102nd, 103rd, and 104th sections. In brief, the duties of the authority are to keep register records of audit firms, specify auditing standards, inspect registered audit institutions, impose required sanctions at the end of inspection and reviews, protect investors, and enhance the audit quality to protect investor and public welfare. The authority makes a detailed review of the independent auditing activity stages from planning audit actions and reporting inspection opinions in terms of auditing standards, quality control standards, and firm procedures. In brief, PCAOB inspects audit firms which control public companies (PCAOB, 2004, p.2)

The inspection activities of PCAOB for controlling the auditing industry can be followed as from 2003. The authority, PCAOB, declares specific parts of the inspection reports to the public (PCAOB Release, No. 104-2004-001, p.3). PCAOB audit reports consist of two parts: publicly accountable and publicly limited. Explaining the complaints and potential imperfections related to quality control of the inspected company in reports is limited by the law. In addition, broadcasting non-public information belonging to inspected companies or their customers is also limited by the same law. However, the auditing issues which the inspection procedures of PCAOB focused on, and also blow-by-blow definitions of the analysis procedures of the authority's personnel, are the publicly accountable parts of audit reports. Related audit reports which comprise two parts clearly explain the audit factors which moved away from auditing standards, independence standards, quality control standards, legal policy, and procedures within inspection of companies. PCAOB continues inspection through non-public investigation or disciplinary proceedings in case of doubt related to a breach that necessitates disciplinary penalty or informing judicial authorities during an inspection. PCAOB declares this by proper disciplinary or enforcement processes (not by inspection reports) to the public if the breach is corporally determined and adequate evidence is obtained (PCAOB, 2004, p.9)

This paper is a case study. Within this scope, the case in question was examined by reviewing official declarations of SEC and PCAOB, public documents of investigations that were opened to the people responsible, formal statements of responsible personnel of KPMG and PCAOB, and articles written by financial and legal circles.

The first of two scandals in the KPMG audit firm reveals that previously completed and reported audit working papers were changed in the light of information that was illegally obtained from PCAOB. KPMG does not rely on the competence of its audits and is apprehensive about the lack of determinations of major mistakes in the financial statements of its customers. When this situation is evaluated in terms of GKDS, we see that several standards were violated. These included the standard for professional attention and care, work area standards, planning and following of assistants, scrutinizing the internal control system, and sufficient evidence gathering standards.

The second scandal was the manipulating of exam results and giving illegally obtained exam questions to auditors. This scandal revealed that KPMG corporate culture showed a tendency towards ignoring social responsibility for company interests. Manipulating exam results and giving illegally obtained exam questions to auditors are actions which are clearly accepted as violating the rules of impartiality of auditors, observing public interest, independency, professional competence, 
attentive working, and avoiding behavior that discredits the profession as per the items of AICPA-Principles of Professional Behavior Law and IFAC-Occupational Ethics Rules.

The research results highlight the importance of required conditions for accepting an audit to be valid by determining certain violated ethical principles and auditing standards. The KPMG scandal caused the effectiveness of public oversight institutions, called by the public as 'inspection of audit', to be queried. Again, the related scandal puts a spotlight on issues such as the necessity of checking the activity and supervision of related institutions and closely examining the actions of the staff of institutions, both within and without the institution. 


\section{Giriş}

Yirmi birinci yüzyılın başlarından itibaren ortaya çıkmaya başlayan finansal skandallar, tüm dünyada denetim piyasasının iyileştirilmesi ihtiyacını ortaya çıkarmıştır. Özellikle Enron vakası, ABD denetim piyasasında, denetçilere ve gerçekleştirilen denetimlere duyulan güvenin sarsılmasında önemli bir kırılmaya neden olmuştur. Söz konusu finansal skandalların ardından, ABD’de denetçi bağımsızlığı ve denetim kalitesinin sağlanması, korunması ve sürdürülebilmesi amacıyla bir dizi önlemler içeren Sarbanes Oxley Yasası (SOX), 2002 yılında yürürlüğe girmiştir.

SOX Yasası ABD'de Menkul Kıymetler Yasası'nın (SEC-1934) ardından denetim mesleği ve denetim piyasası hakkında çıkarılmış en geniş kapsamlı yasa olarak kabul edilmektedir. Yasa, ABD borsalarında işlem gören halka açık şirketlerin mali raporlama sürecine duyulan güvenin arttırılması, şirketlerin finansal raporlama üzerindeki kontrollerin iyileştirilmesi, kurumsal yönetimin etkinliğinin artırılması amaçları ile halka açık şirketlerin tümünü ilgilendirecek bir biçimde hazırlanmıştır. Hazırlanan yasanın en önemli yeniliklerinden biri de şüphesiz, denetim piyasasının denetlenmesi görevini üstlenecek olan Halka Açık Şirketler Muhasebe Gözetim Kurulu (PCAOB) kurulmasıdır. Kurul, Amerikan Sermaye Piyasası Kurumuna bağlı olarak faaliyet göstermek ve denetim firmalarının faaliyetlerini her yönüyle incelemekle yükümlü olarak 2003 yılında faaliyetlerine başlamıştır.

Yasanın beraberinde getirdiği önlemlerin kapsamı ve PCAOB’un üstlendiği görev göz önüne alındığında, halka açık şirketlerin finansal tablo ve bilgilerinin güvenilirliğinin teminatı olan denetimler ile bu denetimleri gerçekleştiren denetim firmalarının güvenilirliğinin artması beklenmektedir. Ancak SOX Yasası ve PCAOB’un getirdiği önlemlerle geçen yaklaşık on beş yılın ardından 2017 yılında, dört büyük denetim firmasından biri olan KPMG’de, bazı PCAOB çalışanlarının da dahil olduğu iki ayaklı yeni bir skandal ortaya çıkmıştır. Bu kapsamda, araştırmanın amacı; 2015-2017 yılları arasında gerçekleşen KPMG skandalını ortaya koymak, PCAOB'ın skandal içindeki rolünü tartışmak ve bu vakada gerçekleşen eylemlerin ihlal ettiği denetim standartları ve etik ilkeleri tespit etmektir. Araştırma sonuçları, ihlal edilen ilkeleri belirlemek suretiyle, bir denetimin geçerli olarak kabul edilmesi için gereken şartların önemine dikkat çekmektedir. Kamuoyunda "denetimin denetlenmesi” olarak anlamlandırılan kamu gözetimi kurumlarının etkinliğinin sorgulanmasına neden olan KPMG skandalı, söz konusu kurulların faaliyetlerinin ve gerçekleştirdikleri incelemelerin gözden geçirilmesi ve Kurul personelinin kurul içerisinde ve hatta kurumdan ayrıldıktan sonraki dönemlerde, eylemlerinin yakından incelenmesi gerektiği konularına dikkat çekmektedir. Bu kapsamda çalışmanın girişi takip eden kavramsal çerçeve kısmında, PCAOB'un tarihçesi kısaca özetlendikten sonra, Kurul görev ve yetkileri ile incelemelerinin içeriği hakkında bilgi verilmiştir. Üçüncü bölümde ise araştırmaya konu olan KPMG Vakası ayrıntıları ile birlikte açıklanmıştır. Son olarak sonuç ve öneriler bölümünde KPMG vakasının ihlal ettiği denetim standartları ve etik ilkeler ortaya koyulmak suretiyle çalışma tamamlanmıştır.

\section{Kavramsal Çerçeve}

Enron başta olmak üzere Worldcom, Parmalat, Xerox gibi finansal skandallar, kamuoyuna açıklanan (hileli) finansal tablolar ve bu tabloların denetim raporlarının güvenilirliğinin sorgulanmasına neden olmuştur. Özellikle, Enron Vakası (ABD) birçok açıdan denetim piyasası hakkındaki yasal düzenlemelerin gözden geçirilmesi ve yeni önlemler alınması için dönüm noktası olmuştur. Skandallarla anılan şirketlerin finansal sıkıntılarının, ilgili bağımsız denetim firmaları tarafından görmezden gelindiği ve hileli finansal raporlama yapmalarına göz yumulduğu iddiaları ile ses getiren davalar açılmıştır (Yalçın, 2018, s. 50). Bu finansal skandalların ve açılan davaların ardından iflasını isteyen denetim firmalarının sebep olduğu zararların büyüklüğü, başta $\mathrm{ABD}$ olmak üzere bütün dünyada bu konuda düzenleme yapılması ihtiyacını ortaya çıkarmıştır. Bu kapsamda, ABD'de denetimde kalitenin sağlanması ve sürdürülmesi amacıyla kapsamlı bir metin hazırlanarak, 30 Temmuz 2002 tarihinde "SOX Yasası" adıyla yayınlanmıştır. SOX, ABD'deki tüm halka açık şirket yönetimleri ve muhasebe firmaları için yeni veya genişletilmiş şartlar belirleyen ABD federal yasasıdır. Yasada yer alan bölümler, halka açık şirketlerin yönetim kurullarının sorumluluklarını kapsamakta, bazı suiistimaller için cezalar içermekte ve Menkul Kıymetler ve Borsa Komisyonu'nun halka açık şirketlerin yasalara nasıl uyacağını tanımlayacak düzenlemeler oluşturmasını gerektirmektedir. On bir bölümden oluşan yasanın ana bölüm başlıkları Tablo-l'de gösterilmiştir. 


\begin{tabular}{|c|l|}
\hline \multicolumn{2}{|l|}{ Tablo 1: SOX Yasası Bölümleri } \\
\hline S. No & Bölüm Başlığı \\
\hline $\mathbf{1}$ & Halka açı şirketler muhasebe gözetim kurulu (PCAOB) \\
\hline $\mathbf{2}$ & Denetçi bağımsızlığı \\
\hline $\mathbf{3}$ & Kurumsal sorumluluk \\
\hline $\mathbf{4}$ & Finansal bilgilerin artırılması \\
\hline $\mathbf{5}$ & Analist çıkar çatışmaları \\
\hline $\mathbf{6}$ & Komisyonun kaynakları ve yetkileri \\
\hline $\mathbf{7}$ & Çalışmalar ve raporlar \\
\hline $\mathbf{8}$ & Kurumsal ve suç unsuru taşıan suistimal sorumluluğu \\
\hline $\mathbf{9}$ & Beyaz yakalıların suçlarına yönelik cezaların artırılması \\
\hline $\mathbf{1 0}$ & Kurumsal vergi iadeleri \\
\hline $\mathbf{1 1}$ & Kurumsal suistimal ve sorumluluk \\
\hline
\end{tabular}

Sayılan ana başlıklar kapsamında yasanın temel amaçları denetçi bağımsızlığı, rotasyon şartı, kurumsal sorumluluk ve PCAOB’ın kurulması olarak sınıflandırılmıştır. SOX Yasası, 102, 103 ve 104'üncü bölümleri ile PCAOB kuruluşunu, amaç ve görevlerini düzenlemektedir. PCAOB’a, Amerikan Hazine Bakanlığı ve Sermaye Piyasası Kurulu tarafından, bağımsız denetimlerin gözetimi, denetçiler için standartlar oluşturulması, denetim firmalarının denetlenmesi ve aykırı durumlar hakkında yaptırımları da içerecek şekilde yetki verilmiştir. Kurulun görevleri, denetim firmalarının sicil kayıtlarının tutulması, bağımsız denetim standartları belirlemek, kayıtlı denetim firmalarının denetlenmesi, denetim ve incelemeler sonucunda gerekli yaptırımların uygulanması, yatırımcı ve kamu yararının korunması amacıyla denetim kalitesini artırmak olarak özetlenebilir. Sayılanlar arasında, Kurulun en önemli görevlerinden biri de tescil kaydı yapılmış olan denetim firmalarının denetlenmesidir. Kurul, denetim firmalarının gerçekleştirmiş oldukları bağımsız denetim faaliyetlerini, faaliyetlerin planlanmasından denetim görüşünün raporlanmasına kadar ki her aşamasını; denetim standartları, kalite kontrol standartları ve firma prosedürleri açısından olmak üzere kapsamlı şekilde incelemektedir. Özetle, PCAOB, halka açık şirketlerin denetimlerini gerçekleştiren denetim firmalarının denetimini gerçekleştirmektedir. Yasa, Kurul'dan; SOX gerekliliklerinin, Kurulun kurallarının, Menkul Kıymetler ve Borsa Komisyonu kurallarının, mesleki standartların ve denetim performansının, denetim raporlarının düzenlenmesi ile bağlantılı olarak mesleki standartları değerlendirmek için müşterileri ilgilendiren konularda sürekli bir inceleme programı yürütmesini talep etmektedir (PCAOB, 2004, s. 2).

Birden fazla etik dışı davranışın bir araya gelerek meydana getirdiği yeni finansal olaylar, SOX, PCAOB ve diğer ülkelerdeki benzer uygulamaların getirdiği önlemlerin yeterli olmadığını ortaya koymuştur. Sadece ABD’de ve KPMG firması özelinde değil hem diğer ülkelerde hem de başta dört büyükler olmak üzere birçok denetim fïrmasının karıştığı onlarca hileli işlem ve uygulamalar kamuoyu, yatırımcılar, düzenleyici kuruluşlar ve şirket yönetimleri tarafından izlenmektedir. Bu nedenle denetim firmalarının faaliyetlerinin denetlenmesi finansal skandalların önüne geçilebilmesi veya skandalların yarattığ zararların en aza indirgenmesi için önemli bir araç olarak görülmektedir. Bu amaçla, 2002 yılında kurulan PCAOB, denetim firmalarının ABD'de 21 Ekim 2003 tarihine kadar; ABD dışındaki denetim firmaları için ise 18 Temmuz 2004 tarihine kadar "Kurul”a kaydolmasını sağlamıştır. Yasanın yürürlüğe girmesiyle birlikte ABD’de 22 Ekim 2003 tarihi itibariyle $598^{1}$ denetim firması tescil edilmiştir. PCAOB’a kaydolan bir muhasebe firması diğer sorumlulukların yanı sıra Kurulun incelemelerine tabidir ve incelemeler esnasında işbirliği yapmak zorundadır.

PCAOB’un, denetim piyasasını denetlemek amacıyla gerçekleştireceği inceleme faaliyetleri 2003 yılından itibaren izlenebilmektedir. Ancak, Kurul tescil edilememiş olan denetim firmalarını inceleyemediğinden, tescil için son tarih olan 21 Ekim 2003 tarihine kadar herhangi bir inceleme gerçekleştirememiştir. Diğer yandan, dört büyükler olarak bilinen denetim firmalarının 2003 yılı için sınırlı denetimlerinin gerçekleştirilebileceği kararlaştırılmıştır. Söz konusu sınırlı denetimlerin kamu yararı ve tam denetim kültürünün getirilmesinde önemli ve temel bir adım olacağı değerlendirilmiştir. PCAOB, 2003 yılında; KPMG LLP, Ernest \& Young LLP, Pricewaterhouse LLP, Deloitte \& Touche LLP'den oluşan dört büyük denetim firmasının sınırlı denetimleriyle inceleme programını başlatmıştır. Dolayısıyla PCAOB'ın 2003 yılından

1 PCAOB 2018 yılı, Y1llık Raporu verilerine göre; 31/12/2018 tarihi itibariyle PCAOB’a kayıtlı denetim firması sayısı 1862'dir. 
itibaren ABD'de gerçekleştirmeye başladığı incelemelerin ilkine ait "İnceleme Raporu” 26 Ağustos 2004 tarihinde yayınlanmıştır. Kurul her inceleme döneminin ardından hazırlanan inceleme raporlarının belirli kısımlarını kamuya açıklamaktadır. Ayrıca Kurul her inceleme raporunu ilgili denetim firmasına, SEC'e, ilgili devlet makamlarına ve ilgili belirli kısımlarını kamuya açıklamaktadır (PCAOB, 2004, s.3). Bu kapsamda, PCAOB’un, kamu yararını ilgilendiren kuruluşları denetleyen bağımsız denetim firmalarını tescil etmek, denetim ve mesleki diğer standartları oluşturmak, tescil edilen denetim firmalarını incelemek ve inceleme sonucunda yasalara, PCAOB ve SEC kurallarına aykırı hareket edilip edilmediğinin tespiti ve gerektiğinde halinde soruşturma açmak olmak üzere dört temel sorumluluğu bulunmaktadır.

PCAOB, inceleme raporlarının konusu olan bağımsız denetimlerde, firmalar tarafından gözden kaçırılan önemli denetim ve muhasebe konularını tespit etmek suretiyle her bir firmanın kalite kontrol sistemlerinin önemli yönleriyle ilgili endişeleri belirlemektedir. Kurulun yasal olarak öngörülen misyonu, yatırımcıların çıkarlarını korumak ve bilgilendirici, adil ve bağımsız denetim raporlarının hazırlanmasında kamu çıkarlarını artırmak için halka açık şirketlerin denetçilerini denetlemektir. Bu görevi yerine getirmek için, Kurul incelemeleri muhasebe mesleğinin meslektaş değerlendirmesi temel görevini üstlenmektedir. Kurul incelemeleri, bir yandan profesyonel muhasebe ve denetim standartlarına teknik uygunluğu incelerken diğer yandan denetimlerin yapıldığı iş bağlamını ve bu bağlamın firma denetim uygulamalarını nasıl etkilediğini incelemektedir. PCAOB, diğer inceleme unsurlarının yanı sıra firma kültürüne, bir firmanın denetim uygulaması ile diğer uygulamaları arasındaki ilişkileri ve bir firmanın ulusal ofisi ile sahadaki ve bağlı kuruluşlardaki personeli arasındaki ilişkiyi de incelemektedir.

PCAOB inceleme raporları kamuya açıklanabilir ve kamuya açıklanması sııılanmış olmak üzere iki kısımdan oluşmaktadır. İncelemesi gerçekleştirilen firmanın kalite kontrolüne ilişkin eleştiriler ve potansiyel eksikler ile incelenen firma veya onların müşterilerine ait kamusal olmayan bilgilere raporlarda yer verilmesi yasa ile sınırlandırılmıştır. Firmanın kalite kontrol sisteminde tespit edilen kusur veya eleştiriler, raporun kamuya açık olmayan kısmında tartışılır ve incelenen Firmanın, rapor tarihinden itibaren 12 ay içinde Kurula hitaben eleştirilere cevap vermek zorunluluğu bulunmakta olup, söz konusu cevap verilmediği sürece ilgili eleştiriler kamuya açıklanmamaktadır. Diğer taraftan PCAOB’un denetim prosedürlerinin odaklandığı denetim konuları ve Kurul personelinin bu konuları incelemek için yürüttüğü prosedürlerin ayrıntılı tanımları, inceleme raporlarının kamuya açıklanabilir kısımlarını oluşturmaktadır. İki kısımdan oluşan söz konusu inceleme raporları, firmaların incelemelerinde, denetim standartlarından, bağımsızlık standartlarından, kalite kontrol standartlarından, yasal politika ve prosedürlerden uzaklaşmış olan denetim unsurlarını açıkça tanımlamaktadır. Bu iki kısmın dışında incelenen firma veya müşterilerine ait finansal bilgiler ile disiplin soruşturması açılması veya diğer düzenleyici kuruluşlara/ adli makamlara yönlendirmeyi gerektiren hususlar kesinlikle inceleme raporlarında yer almamaktadır. Eğer bir inceleme esnasında adli makamlara bilgi verilmesini veya disiplin soruşturma ve cezalarını gerektiren bir ihlale ilişkin yeterli kanıt elde edilmişse, PCAOB buna göre kamuya açık olmayan bir soruşturma veya disiplin soruşturması yoluyla ya da bilgileri uygun bir makama ileterek devam ettirmektedir. İnceleme sonucunda ihlal somut bir şekilde tespit edilirse PCAOB bunu inceleme raporları ile değil uygun disiplin veya icra süreçleri ile kamuya açıklamaktadır (PCAOB, 2004, s. 9). Bu çalışmanın araştırma konusu olan KPMG vakasında; ihlal edilen standartlar ve kurallar hakkında disiplin soruşturması ve adli makamlara haber verilmesini gerektirecek düzeyde somut ve yeterli kanıt bulunduğundan, söz konusu firmanın 2015-2017 yılları arasında gerçekleştirilen incelemelerinde ihlal edilen denetim standartları PCAOB tarafından raporlanmasının yanı sıra; bu ihlallerin gerektirdiği soruşturmalar ayrı şekilde yürütülmüştür. Daha sonra söz konusu ihlallerin soruşturmaları kamuya PCAOB ve SEC tarafından açıklanmıştır.

\section{KPMG Vakası}

SOX Yasası ile birlikte diğer denetim firmaları gibi KPMG firmasın da tüm yönleriyle yasaya uyumlu bir kurumsal yapı oluşturulmuştur. KPMG Global Davranış Kuralları² , kurumun web sitesinde etik ilke ve kurallarla uyumlu maddelerden oluşmaktadır. KPMG’nin etik değerlere bağlılı̆̆ı, kendi sözleriyle "KPMG’de etik ve dürüstlüğe olan bağlılığımızdan ve temel değerlerimizi ve etik karar verme sürecimizi işimizin tüm yönlerine yerleştirme şeklimizle gurur duyuyoruz"

2 Ayrıntılı bilgi için bakınız: https://home.kpmg/xx/en/home/about/who-we-are/governance/global-code-of-conduct.html 
şeklinde ifade edilmektedir. Ancak, KPMG’nin firma kültürünün fiili olarak bu kurallara uyumlu olmadığını düşündüren olaylar kamuoyu tarafından görülmektedir.

KPMG'nin skandallarla ilgili en yaygın bilinen vakası, 2003 yılında, karşıllığında 22 milyon dolar para cezası ödemek zorunda kaldığı, beş ortağının - firmanın profesyonel uygulama departmanı başkanı da dâhil olmak üzere - adının karıştığ1 Xerox şirketinin 1997-2000 yıllarına ait usulsüz ve hileli denetimleridir. Ancak bu skandaldan sonra alınan önlemler de KPMG’nin bazı etik dışı davranışları ve usulsüzlüklerini önlemeye yeterli gelmediği daha sonraki tarihlerde gerçekleşen olaylardan anlaşılmaktadır. Örneğin, KPMG’nin 2014 yılında, Menkul Kıymetler Borsası Kanununun ihlali nedeniyle SEC'ten toplam 8,2 milyon dolar ceza aldığı bilinmektedir (Silverstein, 2019). Söz konusu ihlaller; KPMG’nin, defterlerini denetledikleri şirketlerin iştiraklerine defter tutma ve uzman hizmetleri gibi denetim dışı hizmetleri sağlayarak denetçi bağımsızlık kurallarını çiğnemesi; bazı KPMG personelinin, denetçi bağımsızlık kurallarını daha da ihlal ederek, KPMG denetim müşterisi olan şirketlerde veya şirketlerin iştiraklerinde hisse sahibi olması ve denetçilerin tarafsılılılarını korumalarını sağlamak için denetledikleri halka açık şirketlerden bağımsız kalmasını gerektiren kuralları ihlal etmesi eylemlerinden oluşmaktadır (SEC, 2014).

Diğer taraftan, 2017 yılında KPMG Güney Afrika Ofisi, ülkede dolandırıcılık iddiası ile çöken bir bankanın denetiminde Güney Afrika hükümetinin vergi gelirlerini azaltacak şekilde yanıltıcı bir rapor yayınlamakla suçlanmıştır. Ayrıca, KPMG ile denetim sözleşmesi bulunan, ülkenin en büyük üçüncü bankası olan Absa Grup ve giyim sanayisi liderlerinden Foschini Grup şirketlerinin denetim anlaşmalarını KPMG’nin usulsüz faaliyetleri nedeniyle feshettiği iddia edilmiştir (Henderson, 2019).

Bir başka KPMG skandalı, 2014- 2017 yılları arasında KPMG Hindistan Ofisi Direktörü, Nitesh Jain'in görevi kötüye kullanmak, rüşvet, gizli anlaşmalar yapmak, aile fertlerini üst düzey pozisyonlarda istihdam etmek, etik dışı davranışlarda bulunmak ve dolandırıcılık gibi birçok suçtan yargılanmasıyla sonuçlanmıştır (Ahmed, 2020).

Diğer taraftan yine ABD'de bir başka skandal; 27 Ekim 2016'da, iki Amerikan senatörü Elizabeth Warren ve Edward J. Markey tarafından duyurulan, KPMG’nin Amerikan finans şirketi Wells Fargo'nun 2011-2015 mali tablolarının bağımsız denetçisi olarak rolünün, milyonlarca müşteri hesabını etkileyen dolandırıcılık, milyarlarca dolar zarar ve 5.000'den fazla Wells Fargo çalışanının işten çıkarılması ve Wells Fargo CEO'sunun emekliye ayrılmasıyla sonuçlanmıştır. Dört yıl süresince yürüttüğü denetimlerde etkin bir iç kontrol süreci yürütemediğini kabul etmeyen KPMG, Wells Fargo'nun bağımsız denetçisi rolüyle yüz binlerce müşteriyi etkileyen ve şirket CEO'su işine mal olan dolandırıcılığı önleyememiş ve kamuya açıklayamamıştır (Warren \& Markey, 2017).

KPMG hakkında bir başka usulsüzlük, 2018 yılında İngiltere'de ortaya çıkmıştır. Her yıl denetim firmalarının belirli standartları karşıladıklarından emin olmak için Finansal Raporlama Konseyi (FRC) tarafından İngiltere'de denetimler yapılmaktadır. FRC, İngiltere'nin kurumsal yönetim kodlarını belirleyen, iş dünyasında şeffaflı̆̆ı ve bütünlüğü teşvik eden, yatırımcılara ve şirket raporlarına, denetime ve yüksek kaliteli risk yönetimine yönelik denetimler yapan, denetçilermuhasebeciler için düzenleyici bir kuruluştur. Konsey, 2018 yılında KPMG hakkında yapılan denetimlerde "Bu firmada kalite üzerinde kabul edilemez bir bozulma" tespit ettiğini ve söz konusu firmayı daha yakından inceleyeceğini açıklamıştır. Söz konusu açılamada, KPMG’nin, FTSE $350^{3}$ denetimlerinin \%50'sindeki eksikliklerin (önceki yılki \%35’e kıyasla) sınırlı iyileştirmelerden daha fazla çaba gerektirdiği ifade edilmiştir. KPMG hakkında denetimlerini derinleştiren FRC, 2018-2019 mali yılının da firma tarafından yapılan incelemelerin \%25 oranında artırılacağını bildirmiştir. FRC Başkanı Stephen Haddrill, söz konusu inceleme sonuçları hakkında, "KPMG denetçilerinin, özellikle banka denetimlerinde karşılaştıkları zorluk ve şüphecilik düzeyi de dâhil olmak üzere, denetim için hayati önem taşıyan kalite, grup denetimleri, emeklilik bakiyeleri ve diğer çeşitli faktörleri hakkında iyileştirmeler yapılması gerektiğini” ifade etmiştir. Ayrıca FRC, KPMG'yi sigorta şirketi Quindell denetimi için 3,2 milyon sterlin para cezasına çarptırmış ve aero- motor üreticisi

3 FTSE 350 Endeksi, Londra Menkul Kıymetler Borsası'nda birincil girişleri olan en büyük 352 şirketi içeren bir piyasa değeri ağırlıklı hisse senedi piyasası endeksidir. En büyük 100 şirketin FTSE 100 Endeksi ile bir sonraki en büyük 250 FTSE 250 Endeksi’nin birleşimidir. 
Rolls-Rolyce'nin denetimi ile ilgili de soruşturma başlatmıştır (BBC News, 2018). Yine İngiltere'de, özensiz denetim çalışmaları ve çıkar çatışmaları nedeniyle KPMG, 455 bin sterlin para cezasına ve firmanın Manchester ortağı Nicole Quayle, 29 bin 250 sterlin para cezasına çarptırılmıştır. Güney Afrika düzenleyici kuruluşları ise KPMG’nin ülkedeki yolsuzluklarda rolü olduğunu iddia eden bir çağrıda bulunmuştur (Miller, 2020). KPMG ise iddialar hakkında; "FRC'nin açıkladığı gibi, finansal tabloların gerçeği yansıtması ve dürüstlüğü hakkında sorun olmadı̆̆ı, denetim kalitesinin firmaları için büyük önem taşıdığ ve endişe duyulan alanlara yönelik denetim süreçlerini güncellediklerini” açıklamıştır. Aynı yıl, İngiliz markası Ted Baker'ın KPMG tarafından denetlendiği sırada, 20-25 milyon sterlin olarak tahmin edilen stoklarının, ertesi yılın denetim firması olarak seçilen Deloitte tarafından yapılan denetimlerde 58 milyon sterlin olduğu tespit edilmiştir. İngiltere Avam kamarası, KPMG’nin, stokları sorgulama ve doğrulama sorumluğunu yerine getirmediği iddiasıyla FRC tarafından incelenmesini talep etmiştir (Szajna-Hopgood, 2019).

Diğer taraftan, 2019 yılı Aralık ayında, Avustralya Finansal İncelemesi (AFR), KPMG Avustralya Ofisinde ortaya çıkan bir başka skandalı raporlamıştır. Üst düzey yöneticilerin ve çalışanların, mevzuata uygunluk testi olarak adlandırılan sürekli eğitim sınavlarında usulsüzlük yaptığı yönünde yapılan bir ihbar sonucunda; kapsamlı bir üçüncü taraf soruşturması gerçekleştirilmiş ve iddia doğrulanmıştır. KPMG’nin politikaları, denetçinin bağımsızlığının sağlanması ve yerel düzenleyici gereklilikler hakkında bir yıllık eğitim kursu verilmekte ve kursun sonunda yirmi soruluk bir test yapılmaktadır. Eğitim tamamen rutin ve yaygın bir uygulama olup, genel etik eğitimi, temel uyumluluk konularına ilişkin çeşitli konuları kapsamaktadır. KPMG Avustralya CEO’su, söz konusu sınav aldatma usulsüzlüğünü kabul ederek; 600 ortak ve 5900 diğer denetim personelinin hemen hemen tamamına aynı eğitim ve testin tekrar uygulanacağını duyurarak iddiaları kabul etmiştir (Tadros, 2020). KPMG’nin üst düzey görevlileri avukatlar ile birlikte, e-posta ve dijital dosyaları da içeren geniş çaplı bir araştırma yapmıştır. Bu incelemede, tüm çalışanların sınav usulsüzlüğüne karışmadığı ortaya çıkmasına rağmen, Sydney Ofisi'nden; "Söz konusu olayın KPMG için bir hayal kırıklığı yarattığı, ilgililer hakkında disiplin soruşturmalarının sürdüğü ve sınavların tekrar edileceği” şeklinde açıklama yapılmıştır (Tadros, 2020).

Görüldüğü üzere KPMG çeşitli ülkelerdeki ofislerinde benzer iddialar ve suçlamalarla karşı karşıya kalmış ve hemen hepsinde söz konusu iddialar hem soruşturmacılar tarafından doğrulanmış hem de KPMG yönetimi tarafından gerekli iyileştirmelerin yapılacağı yönünde açıklamalar ile kabul edilmiştir. ABD’de 2015-2017 yılları arasında gerçekleşen skandal ise iki kısımdan meydana gelmektedir. İlki PCAOB'un denetim firmalarına gerçekleştireceği incelemelerden önce hazırladığı, hangi denetim işlerinin inceleneceğini içeren listelerin yasa dışı olarak ele geçirilmesi ve bu bilgiler doğrultusunda geçmiş denetim işlerine ait çalışma kâğıtlarının değiştirilmesidir. İkincisi ise, KPMG denetim ortaklarının sürekli eğitim sınavlarının sonuçlarını manipüle etmesi, sınav sorularının çalınması ve cevapları ile birlikte çok sayıda denetçiyle paylaşılmasıdır. 17 Haziran 2019 tarihinde SEC, KPMG'ye bu iki eylem için verilen yaptırımı (50 milyon dolar para cezası) kamuoyuna duyurmuştur (SEC, 2019b). KPMG ise tüm iddiaları verilen cezalarla birlikte kabul etmiştir. KPMG, elli milyon dolar para cezasının yanı sıra, firmanın etik ve bütünlük kontrollerini ve çeşitli teşebbüslere uygunluğunu inceleme ve değerlendirmek için bağımsız bir danışman tutmak da dâhil olmak üzere ayrıntılı bir dizi tedbir ve uygulamayı da kabul etmiş̧ir. Ayrıca, KPMG’nin hatalı davranışlarını ele alması, kalite kontrollerini daha da güçlendirmesi için alınacak ek tedbirler bağımsız bir danışman tarafından incelenecek ve değerlendirilecektir (SEC, 2019b).

Öte yandan SEC, tüm bu ilgili usulsüzlükler ortaya çıktıktan sonra, ilgili kişiler hakkında idari soruşturma açarak, görevlerinden alınmalarını, uzaklaştırılmalarını sağlamış ve daha sonra adli soruşturmalar yürütülmeye başlanmıştır. 22 Ocak 2018 tarihinde, eski PCAOB çalışanı ve skandal esnasında yeni KPMG ortağı Brian Sweet'in mahkeme ile işbirliği yapmasını da içeren idari soruşturma belgesi ${ }^{4}$ SEC resmi web sitesinde kamuoyu ile paylaşı1lmıştır. Soruşturma, Sweet'in PCAOB'dan gizli bilgileri izinsiz olarak ifşa etmesini ve hem KPMG'ye hem de kendisine menfaat sağlamaya çalışması suçlamalarını ve PCAOB etik standartlarından EC3 Genel İlkeler, EC9 Kamuya Açık Olmayan Bilgiler ve 3500T Geçici etik ve bağımsızlık standartlarının ihlalini içermektedir.

4 SEC: Administrative Proceeding, File No.3-18347, https://www.sec.gov/litigation/admin/2018/34-82557.pdf 
SEC tarafından yapılan açıklamaya göre, KPMG'de 2014 yılında rakip firmaların (diğer üç büyük denetim firmasının) iki katı kadar denetim eksikliği tespit edilmiştir. 2013 yılı PCAOB inceleme raporuna göre, KPMG’nin PCAOB tarafından gerçekleştirilen incelemelerinin \%46'sında; 2014 raporunda ise incelemelerin \%54'ünde eksiklik tespit edilmiştir (Bramwell, 2019b). Bu kapsamda, KPMG’nin PCAOB incelemeleri yıllar itibariyle incelendiğinde; 26 Ağustos 2004 tarihinde yayınlanan ilk rapor 2003 yılı PCAOB sınırlı inceleme raporu olduğu görülmektedir. Söz konusu sınırlı inceleme raporuna göre, on altı denetim faaliyeti incelenmiştir. Söz konusu inceleme faaliyeti; ilk kez gerçekleştiriliyor olması ve sınırlı bir süreyi kapsaması nedeniyle, incelenen faaliyetlerde tespit edilen eksiklikler hakkında yeterli bilgi kamuya açıklanmamıştır. 2004-2008 yıllarında yayınlanan PCAOB inceleme raporlarında, yıl bazında toplam kaç denetim faaliyetinin incelendiği açıklanmamakla birlikte, incelenen denetim faaliyetlerinde tespit edilen eksiklikler tanımlanmıştır. Söz konusu eksiklikler denetim standartlarının ihlal edilmesi, yetersiz uygulanması, iç kontrol sistemi hakkındaki eksiklikler veya kalite kontrol sistemleri ile ilgili eksikliklerden meydana gelmektedir. Diğer taraftan 2004-2008 y1llarına ait incelemelerde tespit edilen eksikliklerin sayı olarak bilgisi verilmemiştir. 2009-2017 yılları arasında yayınlanan inceleme raporlarında ise, yıl bazında kaç denetimin incelendiği ve bu incelemelerde kaç adet eksiklik tespit edildiği istatistiki verilerle açıklanmıştır. PCAOB’un inceleme raporlarına göre 2009-2017 yılları arasında gerçekleştirilen inceleme ve tespit edilen eksikliklerin sayısı ve yüzdeleri Tablo-2'de gösterilmiştir.

Tablo 2: PCAOB, KPMG İnceleme İstatistiği

\begin{tabular}{|r|c|c|c|c|c|c|c|c|c|c|}
\hline Yıllar & $\mathbf{2 0 0 9}$ & $\mathbf{2 0 1 0}$ & $\mathbf{2 0 1 1}$ & $\mathbf{2 0 1 2}$ & $\mathbf{2 0 1 3}$ & $\mathbf{2 0 1 4}$ & $\mathbf{2 0 1 5}$ & $\mathbf{2 0 1 6}$ & $\mathbf{2 0 1 7}$ & Toplam \\
\hline Inceleme Sayısı & 60 & 52 & 52 & 48 & 48 & 52 & 52 & 51 & 52 & $\mathbf{4 6 7}$ \\
\hline $\begin{array}{r}\text { Tespit Edilen } \\
\text { Eksiklik Sayısı }\end{array}$ & 16 & 43 & 30 & 42 & 22 & 28 & 20 & $22 / 27^{6}$ & 26 & $\mathbf{2 5 0}$ \\
\hline Yüzde $^{5}$ & $\mathbf{2 7}$ & $\mathbf{8 3}$ & $\mathbf{5 8}$ & $\mathbf{8 8}$ & $\mathbf{4 6}$ & $\mathbf{5 4}$ & $\mathbf{3 8}$ & $\mathbf{4 3 / 5 3}$ & $\mathbf{5 0}$ & $\mathbf{5 4}$ \\
\hline
\end{tabular}

Tablo-2'de görüldüğü üzere, yıllar itibariyle yapılan incelemelerde tespit edilen eksikliğin yapılan incelemelere oranı dokuz yıllık zaman serisinin beşinde \%50’nin üzerinde seyretmiş ve toplam incelemenin \%54'ünde eksiklik tespit edilmiştir.

İncelemelerde en sık ihlal edilen denetim standartları, 2012 yılından itibaren PCAOB tarafından sınıflandırılarak inceleme raporları aracılığıyla kamuya açıklanmaktadır. Tablo-3'de görüldüğü üzere, altı yıllık zaman serisi içinde en fazla eksiklik tespit edilen denetim standartlar1; 229 ihlal ile AS 2201 Finansal Tabloların Denetimine Entegre Finansal Raporlama Üzerindeki İç Kontrol Denetimi; 81 ihlal ile AS 2301 Denetçinin Önemli Yanlışlık Risklerine Karşı Yanıtları; 49 ihlal ile AS 2315 Denetim Örneklemesi; 40 ihlal ile AS 2501 Muhasebe Tahminlerinin denetlenmesi ve 30 ihlal ile AS 2502 Gerçeğe Uygun Değer Ölçüm ve Açıklamalarının Denetimi olmak üzere sıralanmaktadır. PCAOB “en sık ihlal edilen denetim standartları" başlı̆̆ı altında KPMG'de altı yıl boyunca toplam 500 denetim standardı ihlali tespit etmiştir. KPMG firmasının denetim standardı ihlallerinin 2013 yılından itibaren artış gösterdiği, 2015 yılında nispeten düşüş görülse de, devam eden yıllarda tekrar artış gösterdiği Tablo-3’te görülmektedir.

5 2009-2011 yıllarına ait tespit edilen eksiklikler raporların içerik incelemesi sonucu elde edilmiş olup, 2012 yılından sonraki “eksiklik" verileri yayınlanan raporlarda sunulan tablolardan elde edilmiştir.

62016 yılı incelemesi skandalın ortaya çıkmasından sonra yeniden gözden geçirilmiş ve tespit edilen eksikliğin sayısı ve yüzdesi güncellenmiştir (PCAOB, 2016 yilı KPMG İnceleme Raporu). 


\begin{tabular}{|c|c|c|c|c|c|c|c|}
\hline PCAOB Denetim Standardi ${ }^{7}$ & 2012 & 2013 & 2014 & 2015 & 2016 & 2017 & Toplam \\
\hline AS 1105 Denetim Kanitları & 1 & 6 & 4 & 3 & & 1 & 15 \\
\hline AS 2101 Denetimin Planlanmas1 & 3 & & & 6 & & 1 & 10 \\
\hline $\begin{array}{l}\text { AS } 2201 \text { Finansal Tabloların Denetimine Entegre Finansal } \\
\text { Raporlama Üzerindeki İç Kontrol Denetimi }\end{array}$ & 14 & 20 & 57 & 37 & 51 & 50 & 229 \\
\hline AS 2301 Denetçinin Önemli Yanlışlık Risklerine Karşı Yanıtları & 9 & 8 & 15 & 7 & 19 & 23 & 81 \\
\hline AS 2305 Önemli Analitik Prosedürler & & 4 & 2 & 2 & 2 & 2 & 12 \\
\hline AS 2310 Doğrulama Süreçleri & & & & & 6 & 3 & 9 \\
\hline AS 2315 Denetim Örneklemesi & & 6 & 7 & 10 & 11 & 15 & 49 \\
\hline $\begin{array}{l}\text { AS } 2401 \text { Finansal Tablo Denetiminde Sahteciliğin } \\
\text { Değerlendirilmesi }\end{array}$ & 1 & 1 & 2 & & 1 & & 5 \\
\hline $\begin{array}{l}\text { AS } 2415 \text { Bir İşletmenin Sürekliliği Hakkında Değerlendirme } \\
(\mathrm{GCO})\end{array}$ & & & & & 1 & & 1 \\
\hline AS 2501 Muhasebe Tahminlerinin Denetlenmesi & & 13 & 4 & 8 & 7 & 8 & 40 \\
\hline $\begin{array}{l}\text { AS } 2502 \text { Gerçeğe Uygun Değer Ölçüm ve Açıklamalarının } \\
\text { Denetimi }\end{array}$ & & 6 & 5 & 4 & 9 & 6 & 30 \\
\hline $\begin{array}{l}\text { AS } 2503 \text { Türev Ürünlerin, Riskten Korunma Faaliyetlerinin ve } \\
\text { Menkul Kıymet Yatırımlarının Denetimi }\end{array}$ & & & 2 & & & & 2 \\
\hline AS 2510 Stoklar & & & 1 & & & & 1 \\
\hline AS 2601 Hizmet Kuruluşları & & & & 1 & & & 1 \\
\hline $\begin{array}{l}\text { AS } 2605 \text { Denetçinin Finansal Tabloların Denetiminde İç Denetim } \\
\text { Fonksiyonunu Değerlendirmesi }\end{array}$ & & 1 & 3 & & & & 4 \\
\hline AS 2810 Denetim Sonuçlarının Değerlendirilmesi & 2 & 1 & 3 & 2 & 2 & 1 & 11 \\
\hline Toplam & 30 & 66 & 105 & 80 & 109 & 110 & 500 \\
\hline
\end{tabular}

PCAOB, denetim firması incelemelerinde en sık eksiklik görülen finansal tablo hesapları hakkında 2013 yılından itibaren veri oluşturmaya ve yayınlamaya başlamıştır. KPMG firması için "En Sık Eksiklik Tespit Edilen Finansal Tablo Hesapları" hakkındaki bilgiler Tablo-4'de sunulmuştur. KPMG firması hakkında yapılan incelemelerde 2013-2017 yılları arasında en fazla ihlalin sırasıyla krediler, gelirler ve stoklar hesaplarında tespit edildiği görülmektedir. Söz konusu üç hesabın toplamı, toplam ihlallerin \%70'ini oluşturmaktadır.

Tablo 4: PCAOB İncelemelerinde KPMG'de En Sık Eksiklik Tespit Edilen Finansal Tablo Hesapları İstatistiği

\begin{tabular}{|l|c|c|c|c|c|c|}
\hline Finansal Tablo Hesapları & $\mathbf{2 0 1 3}$ & $\mathbf{2 0 1 4}$ & $\mathbf{2 0 1 5}$ & $\mathbf{2 0 1 6}$ & $\mathbf{2 0 1 7}$ & Toplam \\
\hline Menkul Kiymetler & 3 & 4 & 3 & & 7 & $\mathbf{1 7}$ \\
\hline Ticari Birleşmeler & & 1 & 6 & 10 & 2 & $\mathbf{1 9}$ \\
\hline Mevduat Yükümlülükleri & & & & 10 & 10 & $\mathbf{2 0}$ \\
\hline Türev Aktif ve Pasifler & & & & & 8 & $\mathbf{8}$ \\
\hline Gelir Vergileri & & & 2 & 2 & 3 & 7 \\
\hline $\begin{array}{l}\text { Maddi Olmayan Duran Varlıklarda Değer } \\
\text { Düşüklügüu }\end{array}$ & 4 & 4 & & 4 & 1 & $\mathbf{1 3}$ \\
\hline Stoklar & 16 & 16 & 9 & 13 & 12 & $\mathbf{6 6}$ \\
\hline Krediler & 25 & 26 & & 25 & 22 & $\mathbf{9 8}$ \\
\hline Morgage & 2 & 2 & & 1 & 3 & $\mathbf{8}$ \\
\hline Gelirler & 16 & 16 & 23 & 15 & 25 & $\mathbf{9 5}$ \\
\hline Yatırımlar & & 3 & 10 & 5 & $\mathbf{9 5}$ & $\mathbf{3 6}$ \\
\hline Toplam & $\mathbf{6 6}$ & $\mathbf{7 2}$ & $\mathbf{5 3}$ & $\mathbf{8 5}$ & $\mathbf{9 3}$ & $\mathbf{3 6 9}$ \\
\hline
\end{tabular}

KPMG inceleme raporlarında tespit edilen eksikliklerin yanı sıra, 2015 yılı öncesindeki son bir kaç yılda sürekli eğitim sınavlarında denetim personeli üst üste düşük puanlar aldığı tespit edilmiştir (Bramwell, 2019b). KPMG, bu durumu iyileştirmek için, PCAOB’un denetim eksikliklerini tespit etmesine müdahalede bulunmak üzere, PCAOB çalışanları ile temasa geçerek bu kişilerden yasal olmayan bilgiler edinmiş ve sonrasında bu kişileri bünyesinde istihdam etmek suretiyle

7 PCAOB, AS, Auditing Standards kod numaralı denetim standartları listesi için bakınız: https://pcaobus.org/Standards/Auditing/Pages/default.aspx 
skandalın ilk adımlarını atmış bulunmaktadır. Bu çerçevede, KPMG denetim firmasında 2015-2017 yılları arasında; üç eski PCAOB çalışanı, Brian Sweet, Cynthia Holder ve Jeffrey Wada ile KPMG ortakları, David Middendorf, Thomas Whittle, David Britt ve Scot Marcello’nun karışıı̆ı, "PCAOB Verilerinin Yasadışı Kullanımı ve Eğitim Sınavlarında Hile Yapılması”" hakkında, skandal olarak kabul edilebilecek eylemler ortaya çıkmıştır. Söz konusu olay hakkında 2017-2019 yılları arasında, finans çevrelerince, akademik çevrelerce onlarca makale yayınlanmış ve SEC ve PCAOB gibi düzenleyici kuruluşlarca soruşturma dosyalarını da içeren resmi açıklamalar zaman zaman kamuoyuyla paylaşılmıştır. Söz konusu haber makaleleri ve düzenleyici kuruluş açıklamalarından elde edilen bilgiler ışığında, söz konusu KPMG Vakası aşağıda özetlenmiştir.

2014- 2015 yıllarında PCAOB'un inceleme grubunda yardımcı direktör olarak görev yapmakta olan Brian Sweet PCAOB'dan ayrılırken, yanında KPMG için gizli bilgileri de beraberinde götürmüştür. SEC'in soruşturma dosyasında yer alan bilgilere göre; Sweet, Nisan 2015'te PCAOB Yönetim Kurulundan ayrılmadan kısa bir süre önce dâhili bir PCAOB veri tabanından ofis bilgisayarına KPMG'de kendisine yardımcı olabileceğine inandığı gizli bilgi ve belgeleri kopyalamıştır. Daha sonra Sweet, bu belgeleri ve PCAOB bilgisayarındaki diğer dosyaları kişisel bir sürücüye aktarmıştır. Ayrıca basılı belgeler arasında da işine yarayacağını düşündüklerinin kopyalarını alarak evinde saklamıştır. Söz konusu belgeler; PCAOB denetim planlama bilgileri, denetim kılavuzları ve el kitapları ile gizli denetim yorum formlarının taslaklarını içermektedir. Planlama materyalleri, PCAOB’un 2015 yılında incelemeyi amaçladığı gizli KPMG denetim sözleşmeleri listesini, her denetim için odak alanlarını ve Kurul'un hangi KPMG denetimlerini inceleyeceğine karar verirken kullandığı tüm nicel ve nitel kriterlerin bir listesini içermektedir. Sweet, KPMG'de Profesyonel Uygulama Bölümü ortaklarından biri olarak 4 Mayıs 2015'de göreve başlamakla birlikte aynı zamanda KPMG iç denetimlerinin de baş sorumlusu olmuştur.

Sweet, göreve başladıktan sonra PCAOB belgelerini kişisel sabit diskinden firmadaki bilgisayarına aktarmış ve KPMG'de işe başladığı ilk günden itibaren PCAOB'un incelemeleri hakkında, Middendorf ve Britt ve diğer meslektaşları tarafından sorular yöneltildiğini soruşturmada dile getirmiştir (SEC, 2018). Sweet ifadesinde, KPMG’nin denetlediği bir banka hakkındaki denetimin PCAOB incelemesine konu olup olmayacağı Middendorf'un özellikle merak ettiği bir konu olduğunu söylemiştir. Sweet'in doğrudan ifade etmediğini iddia etmesine rağmen söz konusu incelemenin gerçekleşeceğine dair Middendorf’a dolaylı olarak bilgi verdiği soruşturma sırasında ortaya çıkmıştır. Bu olaydan birkaç gün sonra Whittle aracılığıyla Sweet'den PCAOB tarafından planlanan tüm incelemelerin listesini Middendorf’a vermesi istenmiştir. Sweet, Whittle'a, PCAOB'un o yıl incelemeyi amaçladığı kırk altı (46) KPMG denetimini tanımlayan ve PCAOB'un bu denetimler için gizli odak alanlarını içeren bir PCAOB denetim planlama belgesinin basılı bir kopyasını göstermiştir. Whittle, ertesi gün söz konusu listede yer alan bankacılık müşterilerinin isim listesini göndermesini bir mail aracılığ 1 ile istemiştir. Sweet kendisinden istenen bilgileri yine bir mail aracılığı ile göndermiş ve bu bilgileri vermesinin karşıllı̆ında hakkında takdir yetkisi kullanılmasını talep ettiğini ima etmiştir. Çünkü Sweet, Middendorf, Whittle tarafından KPMG’deki pozisyonunu sağlamlaştırması için bir şeyler yapması gerektiği yönünde telkin edilmektedir. Sweet, firmaya yardım etmek için çalışan bir takım oyuncusu olarak, onlara kimsenin sağlayamayacağı bilgileri vererek KPMG’deki yerini sağlamlaştırmayı planlamıştır. Aslında KPMG şüphe oluşmaması ve yasa dışı bilgi ediniminin örtbas edilmesi için, PCAOB'un hangi denetimleri inceleyeceğini tahmin etmesi için bir bağımsız danışman tutmuştur. Söz konusu danışman ile birlikte hareket etmek üzere Sweet görevlendirilmiş olup; sahip olduğu tüm bilgiler danışmana Eylül 2015’te aktarılmıştır.

Sweet, PCAOB inceleme listesinin yanı sıra inceleme süreçleri ve odakları hakkında da KPMG’ye bilgi vermiştir. Daha sonra Ağustos 2015'de Sweet'in, KPMG'de bir meslektaşına e- mail ile "eski notlarımı kontrol ettim ve dört müşterimizin denetiminin PCAOB inceleme listesinde olmadığını doğrulayabilirim” dediği ortaya çıkmıştır. Devamında, bu denetimler incenlemeyeceği için güvende olduklarını ifade etmiştir. Sweet, KPMG’ye sadece incelemeler hakkında değil yeni müşterilere hazırlanacak teklifler içinde faydalı olacak gizli bilgiler sağlamıştır. Bunlardan en önemlisi 2016 yılı Nisan ayında yeni bir İspanyol bankası için teklif sözleşmesi hazırlayan bir denetim ortağına gizli PCAOB bilgileri sağlayarak rekabet avantajı sağlamış ve söz konusu "yeni” işin alınmasına yardımcı olmuştur.

Tüm bu gizli bilgilerin ifşası KPMG’nin işlerini oldukça kolaylaştırdığından olsa gerek, firma Sweet'den, iyi bir pozisyon önermek kaydıyla, kendisi gibi PCAOB'dan ayrılarak KPMG’ye katılabilecek çalışanların listesini istemiştir. Sweet henüz PCAOB'da çalışırken arkadaşı Holder'la bu konuyu zaten konuşmuş ve gerçekten KPMG'deki ilk gününde üstü Whittle'a, 
Holder'dan bahsetmiş ve Holder'ın özgeçmişini Whittle'a elden vermiştir. Holder, 12 Mayıs 2015'den itibaren KPMG hakkındaki gizli PCAOB incelemesi bilgilerini Sweet’a sızdırmıştır. Bu bilgilerden ilki, KPMG, PCAOB’a denetim hatalarının temel nedenleri hakkında bir savunma yapmak üzere hazırlandığı sırada, PCAOB’un denetim eksikliği eleştirilerinin yer aldığı gizli belgenin gönderilmesi olmuştur.

17 Haziran 2015'te Holder'dan Sweet'a bir kez daha gizli bilgiler gelmiş ve Temmuz 2015'te KPMG Holder’a iş teklif etmiştir. Holder, ertesi ay denetim frimasına İcra Direktörü olarak katılmıştır. Mart 2016'ya gelindiğinde daha önce KPMG denetimleri üzerinde çalışmış ancak daha sonra başka bir bölüme görevlendirilmiş olan PCAOB'da bir Denetim Lideri olan Jeffrey Wada, terfi beklerken, bir başkasının terfi ettirildiğini öğrenmiştir. Soruşturma sırasında, Wada'nın terfi ettirilmemesinden dolayı PCAOB yönetimine çok fazla öfkelendiğini bir iş arkadaşına açıkça belirttiği ortaya çıkmıştır. KPMG denetimlerinden alındığı için erişim izni olmadığı halde 2016 yılı KPMG inceleme listelerini ele geçiren Wada, 28 Mart 2016 tarihinde eski iş arkadaşı Holder’’ arayarak PCAOB'un inceleyeceği on iki (12) müşterinin isimlerini okumuştur. Holder, daha sonra bilginin PCAOB'daki eski bir meslektaştan geldiğini söyleyerek hemen Whittle, Middendorf ve Britt'e aktaran Sweet'e vermiştir.

Sweet başta olmak üzere PCAOB çalı̧̧anlarından alınan gizli bilgiler, yüksek denetim eksikliği yaşayan ve PCAOB inceleme puanlarını yükseltmek isteyen KPMG için oldukça değerli bilgilerdir. Wada'nın verdiği son bilginin ise KPMG için iki ayrı önemi bulunmaktadır. İlki, 2016 yılı Şubat ayında, Middendorf ve KPMG Liderlik ekibinin diğer üyeleri, SEC Baş Muhasebe Ofisi ile katıldığı toplantıda KPMG’nin denetim kalitesi hakkındaki önemli endişeleri yeterince ele alıp almadıkları hakkında eleştirilmiştir. Middendorf, gruba en yüksek önceliğinin KPMG Ulusal Ofisinin denetim kalitesini iyileştirmek için başlattığı çabalardan birini korumak olduğunu söylemiştir. Bu eleştirilerden sonra, KPMG'de Middendorf, Whittle, Britt, Sweet ve Holder tarafindan, incelenecek denetimleri "yeniden gözden geçirmek" ve PCAOB tarafından olası eksiklik bulgularından kaçınmak için revizyonlar içeren gizli "izleme programları" oluşturulmuştur. Bu programlardan biri, bazı bankacılık müşterilerinin Kredi ve Kira Kaybı Karşlıklarının denetimlerine odaklanmıştır. KPMG, PCAOB’un bu alanda tespit ettiği çok sayıda eksikliğe yanıt olarak 2015 yılında Kredi ve Kira Kaybı Karşlıklarının izleme programını oluşturmuştur. Middendorf, denetim kalitesini geliştirmek için çalıştığı ciddiyetin kanıtı olarak söz konusu programın başarısını üst yönetime sunmuştur. İkinci olarak, Wada, KPMG personelinin denetim çalışma kâğıtlarına erişebildiği ve bunları değiştirebildiği bir zamanda, PCAOB'un planlanan yedi banka denetiminin incelemeleri hakkında KPMG'yi uyarmıştır. KPMG, bu sözleşmelerin her biri için zaten denetim raporları yayınlamış olsa da, KPMG’nin politikasının denetim ekiplerinin nihai denetim dosyasını birleştirme yönetim sürecini tamamlamalarına izin verdiği 45 günlük süre içerisindeyken bu bilgi geldiği için inceleme listesinde yer alan tüm denetimleri gizlice yeniden gözden geçirmiştir. Davaların görüldüğü soruşturmada açıklanan iddianameye göre, gizli inceleme programı KPMG’nin denetim çalışmalarını iki kez kontrol etmesine, çalışma kâğıtlarını güçlendirmesine ve bazı durumlarda eksikliklerin tespit edilmesine ya da gerçek denetim esnasında yapılmamış olan denetim çalışmalarının yapılmasına izin vermiştir. Gizli inceleme programında, Middendorf, Whittle, Britt, Sweet ve diğerleri PCAOB'un bu denetimlerde eksiklik bulma riskini en aza indirmek için herhangi bir önlem alınıp alınamayacağını belirlemeye çalışmışıı. Bu incelemede, Middendorf ve Whittle, PCAOB'dan alınan bilgilerin gizliliği konusunda herkesi uyarmıştır. Britt, gizli projeyi gölgelemek için, KPMG’deki diğer kişilere, firmanın Kredi ve Kira Kaybı Karşılıklarının izleme programındaki otuz beş (35) bankacılık sözleşmesinin tamamında olağan iş akışı içinde çalıştıklarını söylemiştir. Ancak aslında sadece yedi bankanın denetimleri Sweet, Holder ve diğer birkaç çalışan tarafından gözden geçirilmiştir.

Ocak 2017'de Wada, tekrar Holder'a 2017 y1lı PCAOB incelemeleri hakkında ön liste vermiştir. 9 Ocak'ta Holder, müşteri listesini Sweet'e aktarmıştır. Aynı gece Sweet, Whittle ve Britt yeni listede yer alan iki denetim için uyarmak amacıyla sözleşme ortaklarına bilgi vermiştir. Wada, 10 Ocak 2017'de Holder’a özgeçmişini eklediği ve içeriğinde "Şimdi kendimi KPMG’ye satmayı deniyorum” yazan bir mail atmıştır. Daha sonra 2 Şubat 2017 tarihinde Wada, Holder’a iki kısa mesaj göndermiştir, ilkinde "Tamam, alışveriş listesi var", ikincisinde "Yıl boyunca ihtiyacınız olan herşey" yazmaktadır. Ertesi gün Holder’’ arayarak, kırk yedi (47) müşteriyi içeren 2017 incelemelerinin listesini vermiştir. Wada’nın verdiği bilgiler arasında bankalar ve PCAOB'un "düşük performans değerlendirmeleri" olan KPMG katılım ortakları listesi için denetim 
odak alanları da bulunmaktadır. Holder aldığı yeni bilgileri Sweet'e, ve o da Whittle'a aktarmıştır. Whittle, Sweet'e söz konusu denetimlerin denetçilerini uyarması talimatını vermiştir. Sweet'ın uyardığı denetim ortaklarından biri olan Chicago'da bir denetçi, 13 Şubat 2017 tarihinde, kendisinin yönetiminde gerçekleştirilmiş bir denetimin PCAOB inceleme listesinde olduğunu, Sweet’in nasıl bilebileceğinden şüphelenerek bu bilgiyi üst amirine bildirmiş ve ardından KPMG Genel Danışmanlık Ofisine haber verilmiştir. Bu olay, ilk skandalın ortaya çıkmasını sağlamıştır. Çünkü Genel Danışmanlık Ofisi konuyu öğrendikten sonra, iddiaları araştırmaya başlamıştır. KPMG’nin ilk soruşturma aşamasında, Sweet ve Holder PCAOB'un 2017 denetim hedeflerini nasıl öğrendiklerini gizlemiş̧ir. Holder, müfettişlere, isimsiz bir postayla, borsada kayıtlı hisse senetleri kısaltmaları içeren sembolleri listesi aldığını söylemiştir. Holder ve Sweet'in bu durumun ortaya çıkmasıyla birlikte delilleri yok etmeye çalıştıkları da ortaya çıkmıştır (Gaetano, 2019). Bu kapsamda Holder’ın ilgili yazılı mesajları, e-postaları ve belgeleri sildiği, konuşmaların izlenememesi için kullan-at telefon ile görüşmeler yaptığ ortaya çıkmıştır. Sweet'in inceleme listesini yakarak KPMG müfettişlerine sahte belgeler sunduğu ortaya çıkmıştır (Bramwell, 2019b).

Yukarıda özetlenen eylemler 2015-2017 yılları arasında iki yıl boyunca gerçekleşmiş, ancak 2017 yılı başında ortaya çıkmış ve 2019 yılında SEC tarafından KPMG'ye verilecek ceza ile birlikte resmen kamuya durulmuştur. SEC, 2018 yılı Ocak ayında resmi web sitesinde anlaşma teklif eden Sweet ve diğer şüpheliler hakkında idari işlem başlattığını duyurmuş ve hazırladığı dosyaları yayımlamışıır. Beşi KPMG ve biri PCAOB çalışanı olmak üzere altı kişi için federal suç duyurusu yapılmıştır. Söz konusu altı kişi, 2018 yılı başında inceleme listesinin sızdırılması skandalında suçlanmıştır. KPMG yöneticisi David Middendorf ve PCAOB eski çalışanı Jeffrey Wada, yolsuzluk zincirinin iki önemli bağlantısı olarak kabul edilmiştir. Bu iki kişi başta olmak üzere KPMG'deki üst düzey yönetimin PCAOB’u ve kamuoyunu dolandırdığı iddia edilmiştir. Altı kişiden, ikisi jüri tarafından suçlu bulunurken, Ulusal Denetimlerden Sorumlu Ortak Whittle ve Sweet ifadelerini değiştirerek, mahkeme ile işbirliği yapmıştır. Sweet mahkemede, KPMG'de işe başladığı ilk haftalarda kendisinden $\mathrm{PCAOB}$ inceleme listeleri hakkında bilgi talep edildiği, bilgi vermekte tereddüt ettiğinde, Middendorf tarafından "Maaşını nerden aldığını hatırlaması" ve "KPMG'ye sadık olması" gerektiğinin hatıllatıldığını ve sürekli olarak bu konuda baskı gördüğ̈nü itiraf etmiş̧ir.

Middendorf, Sweet, Holder, Whittle, Britt ve Scot Marcello 2017 yılı Nisan ayında KPMG’den uzaklaştırılmıştır. Tüm sayılan eylemlerden Middendorf ve beraberinde dört KPMG çalışanı; Thomas Whittle, Brian Sweet, David Britt ve Cynthia Holder, PCAOB'un hangi denetimleri inceleyeceği bilgisini kullanmakla suçlanmıştır. Ancak Marcello, mahkeme tarafından suçlanmamıştır. PCAOB eski çalışanı Jeffreey Wada'da gizli anlaşmalar yapmak, gizli bilgileri çıkar amaçlı satmak ve elektronik ortam verileri ile oynamak suretiyle otoriteyi dolandırmak suçlarından dokuz ay hapis cezası ve üç yıl denetimli tahliyeye mahkûm edilmiştir (Francine, 2019). Diğer kişinin ise duruşması 2020 yılı baharında gerçekleşmek üzere ileri bir tarihe ertelenmiştir. KPMG’nin Denetim Kalitesi ve Profesyonel Uygulamadan Sorumlu Ortağı David Middendorf, 11 Mart 2019'da Manhattan'da bir federal mahkeme tarafından, gizli anlaşma ve elektronik iletişim veya eyaletler arası iletişim tesisini kullanarak otoriteyi dolandırma suçları ${ }^{9}$ da dâhil olmak üzere dört suçtan bir yıl bir gün hapis cezasına mahkûm edilmiştir (Brasseur, 2019). Eski PCAOB çalışanı Cynthia Holder, yaklaşan banka incelemeleri hakkında kamu gözetiminin gizli materyallerini sızdırılmasına yardımcı olmak ve bunları kötüye kullanmak suçlamalarıyla muhasebe ve denetim mesleklerinden ömür boyu yasaklanmış, sekiz ay hapis cezasına ve iki yıl denetimli tahliye cezasına çarptırılmıştır (Bramwell, 2019b).

PCAOB tüm bu olanların ortaya çıkmasından sonra yeniden gözden geçirdiği KPMG incelemelerinde, 2016 y1lı denetimlerinin \%53'ünde, 2017 yılı denetimlerinin \%50'sinde eksiklik tespit etmiş ve inceleme raporları aracılığıyla kamuoyuyla paylaşmıştır. Diğer yandan daha önceden içerden bilgi alarak yeniden gözden geçirdiği on bir denetimi yeniden incelemiş ve dosyalarda sonradan yapılan değişiklikleri/ sahtekârlıkları ortaya çıkarmıştır (Whitehouse, 2019).

8 Ayrıntılı bilgi için bakınız: https://www.sec.gov/news/pressreleases

9 Gizli anlaşma ve ağ sahtekârlığı (Conspiracy and wire fraud): Bir kişinin gizli anlaşmalar yaparak ve elektronik iletişim veya eyaletler arası iletişim tesisini kullanarak dolandırmaya veya para almayı planladığı bir suçtur. https://criminal.findlaw.com/criminal-charges/wire-fraud.html 
Diğer taraftan SEC'in 17 Haziran 2019 tarihli resmi açıklamasında ${ }^{10}$ da ifade edildiği gibi, KPMG denetim elemanlarının sürekli eğitim sınavı soru ve cevaplarını meslektaşlarıyla paylaştıkları da tespit etmiştir (Brasseur, 2019). SEC tarafından denetçilere yönelik zorunlu ve düzenli olarak gerçekleştirilen sınav sorularının ve cevaplarının resimlerinin çekilerek, epostalar ve basılı kopyalar ile dağıtıldığı tespit edilmiştir (SEC, 2019a). Öyle ki, baş denetçilerin astlarına doğru soruları paylaştığı ve cevaplar talep ederek, topladıkları cevapları tüm astlarla paylaştıkları ortaya çıkmıştır. Soruların çalınması, dağıtılması ve cevapların paylaşılmasına ek olarak, KPMG yönetiminin, PCAOB sınavlarının sınav sonuçlarını işleyen HTML sunucu kodlarını değiştirmek, sınav geçme puanı olan "yetmiş" sınırını manuel şekilde \%25 oranında aşağı çekmek ve daha aşağıda bir puanda konumlandırmak eylemleri SEC'in açıkladığı hususlar arasında yer almaktadır. Yapılan açıklamaya göre, müdahaleden önceki sonuçlara göre KPMG personelin büyük çoğunluğunun sınav sorularının dörtte birinden daha azını doğru cevapladıkları tespit edilmiştir. PCAOB Verilerinin Yasadışı Kullanımı usulsüzlüğüne karşın, sınav sonuçlarının manipüle edilmesi ve soruların çalınmasına kaç personelin dâhil olduğu henüz tespit edilememiş olup, bu konudaki soruşturma devam etmektedir. Diğer yandan, daha önceden gerçekleşmiş sınav sonuçlarına manipüle edilmesinde kullanılan sunucu linkine en az dört en fazla yirmi sekiz (28) kez müdahale edildiği düşünülmektedir (Whitehouse, 2019). Söz konusu eylemlerden, KPMG ortaklarından Timoth Daly, Michael Bellach ve John Danovan sorumlu tutulmuş (SEC, 2020) olsa da, daha fazla KPMG personelinin soruların dağıtılmasında payı olduğu tahmin edilmektedir.

Skandalın diğer ayağı olan sınav sonuçlarının sunucular üzerinden değiştirilmesi, ayrıca daha ileri gidilerek sınav sorularının çalınması, cevaplarıyla birlikte sınava girecek personel ile paylaşılması ise kamuoyu tarafından olağanüstü bir komplo ve kasıtlı yolsuzluk olarak kabul edilmiş̧tir (Kelly, 2019). SEC tarafindan yapılan açıklamalara göre, KPMG’den PCAOB incelemeleri hakkında ihbar aldıkları ancak sınav yolsuzluğu hakkında hiçbir ihbar ya da şikâyetin olmadığı bilgisi edinilmiştir. SEC İcra Direktörü Stephanie Avakian tarafından, bu eylem, denetim profesyonellerinin sahip olması gereken eşsiz güvenilir olma pozisyonu açısından çok rahatsız edici olarak değerlendirilmiştir.

KPMG tüm etik dışı eylemlerini itiraf eden bir mektupla, iddia edilen eylemlerin işletmelerinde gerçekten yaşandığını, ancak bu durumdan gerekli dersleri çıkardıklarını, sorumlulukları üzerlerine alacaklarını ifade ettikleri ve aşağıdaki önlemleri alacaklarını ifade ederken, söz konusu mektubun ana başlıkları (Iacone, 2019);

- Söz konusu yolsuzluk eylemlerinde yer alan tüm personelin tespit edilmesi,

- Denetim uygulamaları lideri olan dört kişinin değiştirilmesi,

- Yönetim kuruluna iki bağımsız direktör eklenmesi,

- PCAOB standartlarına uygun teknoloji geliştirmeleri ve yeni denetim yöntemlerinin uygulanması,

- Denetim ekiplerinin çalışmalarını daha erken süreçte tekrar gözden geçirmek için kalite inceleme ekipleri kullanılması,

- Denetim uygulaması dışındaki denetçilerin çalışmalarını değerlendiren iç denetim ekipleri kurulması,

- Ortaklar ve diğer üst düzey liderler için gözden geçirilmiş performans değerlendirmeleri yapılması,

- CEO Lynne Doughtie, dâhil olmak üzere, ortaklar için denetim kalitesi ile ilgili sorumlulukların açıklanması olarak sıralanmıştır.

KPMG gönderdiği mektupta yer alan bu konuların dışında daha fazla açıklama yapmaktan kaçınmış ve tüm soruları cevapsız bırakmıştır. Yukarıda sayılan iyileştirmelerin yanı sıra, KPMG; 2018 yılında denetim uygulamasını yürüten lider ekibi revize etmiş, denetçilerin çalışmalarını değerlendiren iç denetim ekiplerini denetim uygulamasının dışına taşımış ve ortaklar/ üst düzey yöneticiler için performans değerlendirmelerini yeniden düzenlemiştir. 2019 yılı boyunca, KPMG personel değerlendirme çerçevelerini gözden geçirerek, risk değerlendirmesini, iç kontrolleri ve tahmin

10 Ayrıntılı bilgi için bakınız: https://www.sec.gov/news/press-release/2019-95 
yöntemlerini güncellemiş; iş ortağı denetimini ve incelemelerini artırmış ve denetim ekiplerine gerçek zamanlı destek sağlamak için mevcut ortak sayısını artırarak reformlarını sürdürmüştür. Ayrıca, denetimin etkinliğini artırmak için yeni bulut tabanlı denetim sistemi kullanılmaya başlanan KPMG'de, en önemli risk alanlarına odaklanmak için daha büyük veri kümeleri analizi hayata geçirilmiştir. KPMG, denetçi ortak görev süresi, personel düzeyleri, denetim işinin planlanması gibi, etkili denetim kalitesi faktörlerinin çeşitli kombinasyonlarını da denemeye ve araştırmaya devam edeceğini açıklamıştır (Iacone, 2020).

ABD'de gerçekleșen bu son KPMG skandalını, yukarıda kısaca özetlenmiş diğer usulsüzlüklerden ayıran iki husus bulunmaktadır. Birincisi söz konusu skandala düzenleyici ve denetleyici kuruluş (PCAOB) çalışanlarının da karışmış olması, ikincisi ise hiçbir KPMG çalışanının yaklaşık iki yıl süren sınav sorularının çalınması ve/veya sınav sonuçlarının manipüle edilmesi eylemlerini ihbar etmemiş olmasıdır.

\section{Sonuç ve Öneriler}

KPMG denetim firmasında meydana gelen iki skandaldan ilki; PCAOB'dan yasal olmayan şekillerde elde edilmiş bilgiler doğrultusunda daha önceden tamamlanmış ve raporlanmış denetim çalışma kâğıtlarının değiştirilmesi, KPMG’nin, gerçekleştirdiği denetimlerin yeterliliğine güven duymadığı, müşterilerin finansal tablolarındaki önemli yanlışlıkların tespit edilememiş olduğu yönünde endişeli olduğunu ortaya koymaktadır. Bu durum GKDS açısından değerlendirilecek olursa, genel standartlardan, mesleki dikkat ve özen standardı; çalışma alanı standartlarından, planlama ve yardımcıların gözlenmesi, iç kontrol sisteminin incelenmesi ve yeterli kanıt toplama standartlarının ihlal edildiğini göstermektedir.

İkinci skandal olan sınav sonuçlarının manipüle edilmesi ve sınav sorularının yasa dışı şekilde elde edilerek cevaplarıyla birlikte denetçilere dağıtılması; KPMG firma kültürünün, firma menfaatleri karşısında sosyal sorumluluk ilkesinin çiğnenebileceği yönünde eğilim gösterdiğini ortaya koymaktadır. Yöneticilerin zorlamasıyla emirlere itaat eden astlar/ denetçiler için kuruma itaatin; tarafsızlık ve kamuya hizmetin üzerinde olduğu bir firma kültürü ortaya konmuştur. Yönetim kademesinden itibaren yürütülen yolsuzluğun açıklanması bir iç denetim ekibi için zor bir durum olduğu muhakkaktır. Çünkü üst yönetim yozlaştığında tüm kademelerin yozlaşması muhtemel kabul edilir. Kurumda yer alan iç denetim ekibinin kurum içinde gerçekleşen yolsuzlukları görmezden gelmesi hem bağımsızlık hem de iç denetimin etkin çalışmadığını göstermektedir. KPMG’nin her iki ihlalinde de en rahatsız edici ortak nokta, KPMG denetim uygulaması bölümlerinin en üst seviyesindeki yöneticilerin söz konusu ihlallere liderlik etmesidir. KPMG denetim ortaklarının, üst yönetimden gelen yasal olmayan yollarla elde edilmiş sınav sorularını birbirlerine iletmeleri ve bu konuda hiçbir ihbar ya da ifşanın gerçekleşmemesi, firma denetçilerinin bağımsızlığına gölge düşürmek suretiyle, GKDS'dan bağımsızlık standardının yerine getirilmediğini göstermektedir. Sınav sonuçlarının manipüle edilmesi, sınav sorularının yasa dışı şekilde elde edilmesi, yayılması, sınavlara bu yasa dışı bilgilerle dâhil olunması eylemleri, Amerikan Sertifikalı Kamu Muhasebecileri Enstitüsü’nün (AICPA) Mesleki Davranış Yasası İlkeleri ve Uluslararası Muhasebeciler Federasyonunun (IFAC) Meslek Etiği Kurallarında yer alan; denetçilerin tarafsızlığı, kamu çıkarı gözetme, dürüstlük, bağımsızlık, mesleki yeterlilik ve özenli çalışma maddelerinin ve özellikle mesleği itibarsızlaştıracak davranışlarda bulunulmaması kuralının ihlal edilmesi olarak değerlendirilmektedir.

Özetle, araştırma konusu olan KPMG skandalı denetim standartları ve etik ilkeler açısından incelendiğinde, PCAOB denetim standartlarının, Etik ilkelerin ve SEC kurallarının birden fazla eylem ile ihlal edildiği görülmektedir. Söz konusu ihlal edilen kurallardan bazıları aşağıda sıralanmıştır:

- PCAOB Denetim standartlarından; AS 1005 Bağımsızlık, AS 1010 Bağımsız Denetçinin Eğitimi ve Yeterliliği, AS 1015 Mesleki özen ve titizlik, AS 1105 Yeterli kanıt toplanması, AS 1110 Kalite kontrol sisteminin, AS 1201 Denetim Görevinin Denetimi, AS 1215 Denetim Belgeleri, AS 2101 Denetim Planlaması, AS 2110 Önemli Yanlışlık Risklerini Belirleme ve Değerlendirme, AS 2200 Finansal Raporlama Üzerinde İç Kontrol Denetimi, AS 2201 İç kontrol sisteminin etkinliği standartlarının, 
- PCAOB etik standartlardan; EC3 Genel İlkeler, EC9 Kamuya Açık Olmayan Bilgiler ve 3500T Geçici Etik ve Bağımsızlık standartlarının ve

- SEC'in 4C- "Başkalarını temsil etmek için gerekli niteliklere sahip olmak", "Karakter ya da dürüstlükten yoksun ya da etik dışı ya da uygunsuz mesleki davranışlarda bulunmak" ve 21C-"Menkul kıymetler yasalarının veya kural ve düzenlemelerinin herhangi bir hükmünü kasten ihlal etmek veya ihlal edilmesine kasten yardım etmek" kuralları.

Bu kapsamda, söz konusu skandal, PCAOB'ın kurumsal güvenilirliğinin sarsılması ve kamuoyunun bağımsız denetime güveninin sarsılması olmak üzere iki önemli sonuç doğurmuştur. KPMG, yıllar itibariyle gerçekleştirilen PCAOB incelemelerinden üst üste aldığı düşük değerlendirmeleri düzeltmek amacıyla gerçekleştirdiği bu yasal olmayan eylemlerle yalnızca firmanın değil, PCAOB’un da bağımsızlığının ve güvenilirliğinin sarsılmasına neden olmuştur. Bu eylemler, denetim piyasasına hem kamu güveni hem de fiili denetim kalitesinin sorgulanması açısından görülenden daha büyük zararlar vermiştir (Bramwell, 2019a). Ayrıca birbiri ile karşılaştırıldığında, sınav skandalı, PCAOB skandalından daha uzun süren, daha fazla KPMG çalışanın dâhil olduğu ve çalışanların etik kültürünün zayıflığını daha derin şekilde ortaya koyan bir skandal olarak değerlendirilebilir.

SEC tarafından 17 Haziran 2019 tarihinde yapılan açıklamada, İcra Bölümü Eş Direktörü Steven Peikin, "Burada söz konusu hatalı davranışın geniş liği ve ciddiyeti açıkçası hayret verici" diyerek ortaya çıkan durumunönemine vurgulamaktadır. Ancak, SEC'in vurguladığı öneme uygun ceza verilip verilmediği kamuoyu nezdinde tartışılmaya devam etmektedir. SEC, bu rekor cezayı yalnızca inceleme listelerinin yasa dışı ele geçirilmesi ve kullanılması eylemlerinden ötürü uygulamış olup, henüz sınavlarda yapılan usulsüzlükler hakkında soruşturma tamamlanmamışıı. SEC tarafından sınav hilesi ile ilgili açıklanmış tek ceza, usulsüz eyleme karıştığı tespit edilen Daly, Bellach ve Danovan'a sırasıyla üç, iki ve bir yıl denetim görevinden men edilme cezasıdır. Denetim piyasasının ilgili tarafları; KPMG’ninde kabul ettiği 50 milyon dolarlık cezanın ve denetimden men cezalarının etkin bir caydırma yaptırımı olup olmadığı, yalnızca isimleri anılan dokuz kişinin yargılanması ve cezalandırılması, soruşturmanın genişletilmemesi, her iki skandala karışmış olabilecek başka KPMG ve PCAOB çalışanlarının olup olmadığı hakkındaki soruların yeterince yanıtlanmadığını düşünmektedir.

Ayrıca, 2019 yılı Kasım ayında, ABD Hükümet Gözetimi Projesi (The Project On Government Oversight- POGO) tarafından yapılan bir incelemeye göre, PCAOB'da çalışanlarının en az \%40'ının daha önce dört büyük denetim firmasından birinde çalışıı̆ı ortaya çıkmıştır. Bu oranla ilişkili olarak, dört büyük denetim firması ile PCAOB arasındaki bu bağın, denetim firmalarının incelemelerde tespit edilen eksiklikleri nedeniyle yeterince cezalandıramadığını işaret etmektedir (POGO, 2020). Söz konusu rapora göre, PCAOB 16 yıl boyunca gerçekleştirdiği incelemelerde dört büyük denetim firmasına ait ABD ofislerinde 808 hatalı denetim listelerken, bunlardan ancak 18'i için disiplin işlemi başlattığı görülmektedir. Diğer taraftan, PCAOB çalışanlarının, kurumdan ayrılarak daha önce incelemelerinde görev aldıkları denetim firmalarının çalışanı veya ortağı olarak denetim mesleğine devam edebilmeleri, sorgulanması gereken bir başka unsur olarak dikkat çekmektedir. KPMG vakasındaki Brian Sweet, Cyhthia Holder ve Jeffrey Wada kasitlı olarak gizli bilgi ve belgeleri sızdırmamış olsalardı dahi, daha önce çalıştıkları kurumda edindikleri mesleki (gizli) bilgilerin hafızalarında olmaması ve bu bilgileri kullanma arzusunu dürüstlük, sır saklama, tarafsızlık, sosyal sorumluluk ve meslek etiği ilkeleri çerçevesinde bastırabilecekleri ihtimal dâhilinde kabul edilebilir mi?

Sonuç olarak, bu vaka araştırmasl, dört büyük denetim firmasından biri olan KPMG’nin bugünden çok da uzak olmayan bir tarihte gerçekleştirdiği yolsuzlukların kamuya açıklanan kısımlarını içermektedir. SEC ve PCAOB tarafından kamuoyuyla paylaşılmayan başka ihlal unsurlarının olup olmadığı elbette merak konusudur. Diğer yandan bu skandal akıllara aşağıdaki soruları getirmektedir:

- Eğer bu skandal ortaya çıkmasaydı, KPMG’nin bu eylemleri daha ne kadar süre devam edecekti?

- KPMG başka hangi konularda yolsuzluğa başvurmaktadır?

- KPMG’nin kalite kontrol sistemi halen kabul edilebilir mi? 
- PCAOB'da daha başka yolsuzluk yapan personel var mıdır? Var ise nasıl tespit edilecektir?

- PCAOB çalışanlarının ne kadarı daha önce dört büyük denetim firmalarında görev yapmaktaydı?

- PCAOB'dan ayrılan denetim meslek mensuplarının ne kadarı, kuruldan ayrıldıktan sonra dört büyük olarak adlandırılan denetim firmalarında istihdam edilmektedir?

- Söz konusu yolsuzluklar diğer denetim firmalarında da mevcut mudur?

- PCAOB bu konuda tedbir almak için neler yapacaktır?

- Aynı ihlalleri dört büyükler dışında bir denetim firması gerçekleştirmiş olsaydı, düzenleyici kurumların tavrı nasıl olurdu?

Yukarıdaki sorular genişletilebilmekle birlikte, kamu gözetimi kurulları ve denetim firmaları hakkında bu ve benzeri sorulara verilecek cevaplar, gelecek yeni çalışmalara araştırma konusu olabilecektir.

Hakem Değerlendirmesi: Dış bağımsız.

Çıkar Çatışması: Yazar çıkar çatışması bildirmemiştir.

Finansal Destek: Yazar bu çalışma için finansal destek almadığını beyan etmiştir.

Peer-review: Externally peer-reviewed.

Conflict of Interest: The author has no conflict of interest to declare.

Grant Support: The author declared that this study has received no financial support.

\section{Kaynakça}

Ahmed, A. (2020, May 8). KPMG India cheating scandal 2020: Director nitesh jain exposed. Retrieved from https://medium.com/@ abu137/kpmg-india-cheating-scandal-2020-director-nitesh-jain-exposed-2a745327d44

BBC News. (2018, June 18). KPMG's audit work unacceptable, says watchdog. Retrieved from https://www.bbc.com/news/business-44526486 Bramwell, J. (2019a, June 25). Which KPMG scandal is worse: PCAOB "steal the exam" or cpe trainig exam cheating? Retrieved from https:/goingconcern.com/which-kpmg-scandal-is-worse-pcaob-steal-the-exam-or-cpe-training-exam-cheating/

Bramwell, J. (2019b, August 9). Ex-KPMG executive director who was major player in PCAOB cheating scandal sentenced to eight months in jail. Retrieved from https://goingconcern.com/ex-kpmg-executive-director-who-was-major-player-in-pcaob-cheatingscandal-sentenced-to-eight-months-in-jail/

Brasseur, K. (2019, October, 15). Ex-PCAOB leader gets prison time for role central to KPMG scandal. Retrieved from https://www. complianceweek.com/accounting-and-auditing/ex-pcaob-leader-gets-prison-time-for-role-central-to-kpmg-scandal/27877.article Francine, McK. (2019, June 26). An SEC fine for KPMG in the PCAOB data theft scandal and another horrible revelation, Retrieved from http://retheauditors.com/2019/06/26/what-are-the-chances-of-a-significant-sanction-or-fine-for-kpmg/

Gaetano, C. (2019, September 12). Former KPMG managing partner sentenced to a year and a day in prison for PCAOB cheating scandal. Retrieved from https:/www.nysscpa.org/news/publications/the-trusted-professional/article/ former-kpmg-partner-sentenced-to-a-year-and-a-day-in-prison-for-pcaob-cheating-scandal-091219

Henderson, R. (2019, December 2). KPMG South Africa makes headway rebuilding image after scandals. Retrieved from https://www. accountingtoday.com/articles/kpmg-south-africa-makes-headway-rebuilding-image-after-scandals

Iacone, A. (2019, February 5). Reformed KPMG emerges from cloud of scandal, Retrieved from https://news.bloombergtax.com/financialaccounting/reformed-kpmg-emerges-from-cloud-of-scandal.

Iacone, A. (2020, March 19). KPMG, PwC work to repair reputations following scandals, fines. Retrieved from https://news.bloombergtax. com/financial-accounting/kpmg-pwc-work-to-repair-reputations-following-scandals-fines 
Kelly, M. (2019, June 19). Questions on KPMG ethics fiasco. Retrieved from http://www.radicalcompliance.com/2019/06/19/ questions-kpmg-ethics-fiasco/

Miller, H. (2020, April 2). KPMG reprimanded, again, and fined \$560,000 for audit failings. Retrieved from https://www.bloomberg. com/news/articles/2020-04-02/kpmg-reprimanded-again-and-fined-560-000-for-audit-failings.

Public Company Accounting Oversight Board, (2002), The sarbanes-oxley act, public law, Retrieved from https://pcaobus.org/About/ History/Documents/PDFs/Sarbanes_Oxley_Act_of_2002.pdf

Public Company Accounting Oversight Board, (2004, August 26), Report on 2003 limited inspection of KPMG LLP issued by the public company accounting oversight board august 26, 2004. Retrieved from https://pcaobus.org/Inspections/Reports/Pages/default. aspx\#k=kpmg\%2011p

Public Company Accounting Oversight Board, (2005, September 29), Report on 2004 Inspection of KPMG LLP, issued by the public company accounting oversight board september 29, 2005, PCAOB Release No. 104-2005-088. Retrieved from https://pcaobus.org/ Inspections/Reports/Pages/default.aspx \#k=kpmg\%201lp

Public Company Accounting Oversight Board, (2007a, January 11), Report on 2005 inspection of KPMG LLP issued by the public company accounting oversight board january 11, 2007, PCAOB Release No. 104-2007-002. Retrieved from https://pcaobus.org/Inspections/Reports/ Pages/default.aspx $\# \mathrm{k}=\mathrm{kpmg} \% 201 \mathrm{p}$

Public Company Accounting Oversight Board, (2007b, July 26), Report on 2006 inspection of KPMG LLP issued by the public company accounting oversight board july 26, 2007, PCAOB Release No. 104-2007-106. Retrieved from https://pcaobus.org/Inspections/Reports/ Pages/default.aspx $\# \mathrm{k}=\mathrm{kpmg} \% 201 \mathrm{p}$

Public Company Accounting Oversight Board, (2008, August 12), Report on 2007 inspection of KPMG LLP Issued by the Public Company Accounting Oversight Board August 12, 2008, РСAOB Release No. 104-2008-146. Retrieved from https://pcaobus.org/Inspections/Reports/ Pages/default.aspx $\# \mathrm{k}=\mathrm{kpmg} \% 201 \mathrm{p}$

Public Company Accounting Oversight Board, (2009, June 16), Report on 2008 inspection of KPMG LLP (headquartered in New York, New York) issued by the public company accounting oversight board june 16, 2009 PCAOB Release No. 104-2009-096. Retrieved from https://pcaobus.org/Inspections/Reports/Pages/default.aspx\#k=kpmg\%201lp

Public Company Accounting Oversight Board, (2010, October 5), Report on 2009 inspection of KPMG LLP (headquartered in New York, New York) issued by the public company accounting oversight board october 5, 2010, PCAOB Release No. 104-2010-132. Retrieved from https://pcaobus.org/Inspections/Reports/Pages/default.aspx\#k=kpmg\%201lp

Public Company Accounting Oversight Board, (2011, November 8), Report on 2010 inspection of KPMG LLP (headquartered in New York, New York) issued by the public company accounting oversight board november 8, 2011, PCAOB Release No. 104-2011-288A. Retrieved from https://pcaobus.org/Inspections/Reports/Pages/default.aspx\#k=kpmg\%201lp

Public Company Accounting Oversight Board, (2012, August 15), Report on 2011 inspection of KPMG LLP, (headquartered in New York, New York), issued by the public company accounting oversight board august 15, 2012, PCAOB Release No. 104-2012-199A. Retrieved from https:/pcaobus.org/Inspections/Reports/Pages/default.aspx\#k=kpmg\%201lp

Public Company Accounting Oversight Board, (2013, July 30), Report on 2012 inspection of KPMG LLP (headquartered in New York, New York) issued by the public company accounting oversight board july 30, 2013, PCAOB Release No. 104-2013-147. Retrieved from https://pcaobus.org/Inspections/Reports/Pages/default.aspx\#k=kpmg\%201lp

Public Company Accounting Oversight Board, (2014, September 24), Report on 2013 inspection of KPMG LLP (headquartered in New York, NY) issued by the public company accounting oversight board september 24, 2014, PCAOB Release No. 104-2014-167. Retrieved from https://pcaobus.org/Inspections/Reports/Pages/default.aspx \#k=kpmg\%201lp

Public Company Accounting Oversight Board, (2015, October 15), Report on 2014 inspection of KPMG LLP (headquartered in New York, New York) issued by the public company accounting oversight board october 15, 2015. Retrieved from https://pcaobus.org/Inspections/ Reports/Pages/default.aspx\#k=kpmg\%201lp 
Public Company Accounting Oversight Board, (2016, November 9), Report on 2015 inspection of KPMG LLP (headquartered in New York, New York) issued by the public company accounting oversight board november 9, 2016. Retrieved from https://pcaobus.org/ Inspections/Reports/Pages/default.aspx $\# \mathrm{k}=\mathrm{kpmg} \% 201 \mathrm{p}$

Public Company Accounting Oversight Board, (2019a, January 15), Report on 2016 inspection of KPMG LLP (headquartered in New York, New York) issued by the public company accounting oversight board january 15, 2019, PCAOB Release No. 104-2019-001. Retrieved from https://pcaobus.org/Inspections/Reports/Pages/default.aspx\#k=kpmg\%201lp

Public Company Accounting Oversight Board, (2019b, January 24). Report on 2017 inspection of KPMG LLP (headquartered in New York, New York) issued by the public company accounting oversight board january 24, 2019, PCAOB Release No. 104-2019-002. Retrieved from https://pcaobus.org/Inspections/Reports/Pages/default.aspx\#k=kpmg\%201lp

The Project On Government Oversight. (2020). New POGO report illustrates extent of revolving door between accounting firms and their regulator. Retrieved from https://www.pogo.org/press/release/2020/new- pogo- report- illustrates-extent- of-revolving-door-betweenaccounting-firms-and-their-regulator/

Securities and Exchange Commission for Immediate Release (2014). SEC charges KPMG with violating auditor independence rules. Retrieved from https://www.sec.gov/news/press-release/2014-12

Securities and Exchange Commission, (2018). Administrative proceeding, file no. 3-18347. Retrieved from https://www.sec.gov/litigation/ admin/2018/34-82557.pdf

Securities and Exchange Commission Press Release, (2019a). SEC charges three former KPMG audit partners for exam sharing misconduct. Retrieved from https://www.sec.gov/news/press-release/2020-115

Securities and Exchange Commission Press Release, (2019b), KPMG paying $\$ 50$ million penalty for illicit use of PCAOB data and cheating on training exams. Retrieved from https://www.sec.gov/news/press-release/2019-95

Silverstein, S. (2019, June 21). KPMG's ethics crisis- and the lesson it teaches leaders about accountabilitty. Retrieved from https:// samsilverstein.com/kpmgs-ethics-crisis-and-the-lesson-it-teaches-leaders-about-accountability/

Szajna-Hopgood, A. (2020, February 10). Calls for watchdog to review KPMG’s £58m Ted Baker accounting scandal. Retrieved from https://www.retailgazette.co.uk/blog/2020/02/calls-for-watchdog-to-review-kpmgs-53m-ted-baker-accounting-scandal/

Tadros, E. (2020, March 12). KPMG retakes independence exam amid cheating scandal. Retrieved from http://starlingtrust.com/ kpmg-retakes-independence-exam-amid-cheating-scandal-financial-review/

Warren E. ve Markey E.J. (2017, April 25). Letter on KPMG's role and findings as the independent auditor of Wells Fargo's financial statements from 2011-2015. Retrieved from https://www.warren.senate.gov/files/documents/2017_04_25_Letter_\%20to_PCAOB.pdf

Whitehouse, T. (2019, June 19). KPMG fallout: Cheating allegations raise new questions. Retrieved from https://www.complianceweek. com/accounting-and-auditing/kpmg-fallout-cheating-allegations-raise-new-questions/27281.article

Yalçın, N. (2018). Zorunlu denetim firması rotasyonunun bağımsız denetim kalitesine etkisi: Borsa İstanbul'da bir uygulama. Osmaniye Korkut Ata Üniversitesi, Sosyal Bilimler Enstitüsü, Yayınlanmamış Doktora Tezi. 
